\title{
Mesophotic gorgonian corals evolve multiple times and faster than deep and shallow lineages
}

\author{
Juan A. Sánchez ${ }^{1}$, Fanny L. González-Zapata ${ }^{1}$, Carlos Prada ${ }^{2}$ \\ \& Luisa F. Dueñas ${ }^{3}$ \\ ${ }^{1}$ Laboratorio de Biología Molecular Marina (BIOMMAR), Departamento de Ciencias Biológicas-Facultad \\ de Ciencias, Universidad de los Andes, Bogotá, Colombia \\ ${ }^{2}$ University of Rhode Island, Kingston RI 02881, USA \\ 3 Departamento de Biología, Universidad Nacional de Colombia, Bogotá, Colombia
}

Keywords: Mesophotic Coral Ecosystems, Gorgonians, Octocoral, Time-calibrated phylogeny,

Caribbean, Deep-sea

\section{Summary}

Mesophotic Coral Ecosystems (MCEs) promise hope for the shallow-water biota enduring rising temperatures and multiple environmental stressors. Using a time-calibrated molecular phylogeny (mtDNA: mtMutS), we examined the lineage membership of mesophotic gorgonian corals (Octocorallia: Cnidaria) in comparison to shallow and deep-sea lineages of the wider Caribbean-Gulf of Mexico and the Tropical Eastern Pacific. Our results show mesophotic gorgonians originating multiple times from old deep-sea octocoral lineages, whereas shallow-water species comprise younger lineages. The mesophotic gorgonian fauna in the studied areas are related to their zooxanthellate shallow-water counterparts in only two clades (Gorgoniidae and Plexauridae), where the shallow-deep gradient could serve as a driver of diversification. Interestingly, mesophotic clades have diversified faster than either shallow or deep clades. One of this groups with fast diversification is the family Ellisellidae, a major component of the mesophotic gorgonian coral assemblage worldwide.

\section{Introduction}

Gorgonian corals (Cnidaria: Octocorallia) generate a unique seascape in the shallow-water communities of the Western Atlantic and adjacent seas, including Mesophotic Coral Communities (MCEs). MCEs include a diverse gorgonian fauna [1], which increases the prospect on this environment as refugia for endangered shallow-water biota under current global change [2]. Their tall branching colonies, sometimes reaching high

*Author for correspondence (juansanc@uniandes.edu.co). 
bioRxiv preprint doi: https://doi.org/10.1101/2020.12.17.422867; this version posted December 18, 2020. The copyright holder for this preprint (which was not certified by peer review) is the author/funder, who has granted bioRxiv a license to display the preprint in perpetuity. It is made available under aCC-BY 4.0 International license.

densities, form an animal forest of great diversity from shallow to mesophotic and deeper ecosystems $[1,3]$.

This particular assemblage thrives at both coasts of tropical and sub-tropical America [4], Brazil [5], the west coast of Africa [6], and even some temperate areas in the Atlantic [7,8] and the Mediterranean Sea [9]. Yet, it is unknown if gorgonians at MCEs are the extension of shallow or deep-sea communities or whether mesophotic octocorals comprised different evolutionary lineages [1]; moreover, the role of this ecosystem on octocoral diversification is unknown. In this study, we reconstructed a time-calibrated molecular phylogeny for 242 gorgonian coral species using mtDNA (mtMutS), including numerous new sequences of mesophotic gorgonian corals from the Caribbean Sea (down to $115 \mathrm{~m}$ ) and many available sequences in Genbank from related species in the Gulf of Mexico, eastern tropical Pacific, western Atlantic, Indo-Pacific, and the Mediterranean Sea. We tested whether mesophotic lineages descent from a single ancestor from either shallow or deep-water areas or if instead have multiple origins. We also compared rates of diversification across shallow, mesophotic and deep-water gorgonians.

\section{Materials and Methods}

Using Closed-Circuit Rebreather-CCR and Trimix, we surveyed gorgonian corals from $115 \mathrm{~m}$ up to $45 \mathrm{~m}$ in MCEs in three locations in the Colombian Caribbean: San Andrés island (Archipelago of San Andrés, Providencia and Santa Catalina), Barú island diapiric banks and the Deep-sea Corals National Park (both near Cartagena). A dry voucher for each colony is available at the Museo de Historia Natural ANDES (ANDES-IM 4132 to ANDES-IM 4802). Research and collection of specimens were approved by the National Environmental Licensing Authority (ANLA, Spanish acronym): Collection Framework Agreement granted to Universidad de los Andes through resolution 1177 of October 9, 2014 - IBD 0359. Since we did the collections during previous studies, detailed information on the sites and study areas is already available [10-12].

Together with our new material, we examined their phylogenetic affiliations in comparison to shallow and deep-sea lineages of the wider Caribbean-Gulf of Mexico and Tropical Eastern Pacific using the available information (See supplementary table 1).

Samples were fixed in both Ethanol $95 \%$ and DMSO. Total genomic DNA of each specimen was extracted from about $5 \mathrm{~mm}^{2}$ of tissue following a standard CTAB Phenol:Chloroform:Isoamyl Alcohol protocol [13]. DNA 
bioRxiv preprint doi: https://doi.org/10.1101/2020.12.17.422867; this version posted December 18, 2020. The copyright holder for this preprint (which was not certified by peer review) is the author/funder, who has granted bioRxiv a license to display the preprint in perpetuity. It iş made available under aCC-BY 40 International license.

quality was assessed in $1 \%$ agarose gel electrophoresis in 1 X TBE buffer. Gels were dyed with ethidium

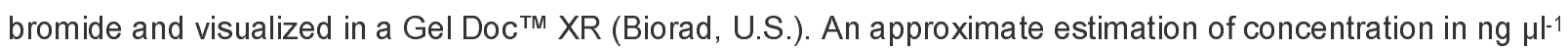
and purity (260/280 and 260/230 ratios) of each DNA sample was assessed with a NanoDrop (Thermo Scientific, U.S.). The mtMutS region was targeted using the protocols described in the literature [14].

Phylogenetic relationships and times of divergence between shallow and deep-sea gorgonian lineages were co-estimated using BEAST ver. 1.8.2. Divergence times were estimated using a relaxed molecular clock with log-normal uncorrelated rates and assuming a Birth-Death Incomplete Sampling speciation tree prior. The analysis was run four independent times under a GTR model and used $10^{7}$ generations and default heating values on three Metropolis-coupled chains. Trees and parameters were sampled every 1,000 generations and the first $10 \%$ of the samples were discarded as burn-in. We used Tracer ver. 1.8 to check for adequate convergence and confirmed effective sample size (ESS) greater than 200. LogCombiner ver. 1.8 and TreeAnnotator ver. 1.8 were used to combine and summarize tree files, obtain a maximum clade credibility consensus tree, and calculate $95 \%$ credibility intervals. We also ran the analysis on an empty dataset, sampling from the prior distribution to evaluate the influence of the priors on the posterior distribution estimates [15]. We followed a time-calibrated molecular approach using fossil calibration points [14]. As calibration points, we employed the oldest known fossil for the families Elliseliidae (Kuzmicheva 1987) and Keratoisidinae [16], and for the genus Eunicella [17]. The minimum age of each fossil was treated as a minimum constraint on the age of the stem group node using a log-normal distributed prior. The standard deviation was calculated in such a way that $95 \%$ of the probability density lies between the minimum constraint and the oldest date of the geological range of the fossil. Letters correspond to monophyletic lineages explained in the text.

To test if clades from different depths (shallow, mesophotic of deep) differ in their diversification rates, we used the multi-state character extension (MUSSE) model as implemented in the package diversitree [18]. Initially we fit a "null" model, in which all birth and death rates were equal between states, the character evolution was ordered (shallow <-> mesophotic <-> deep), and there is a single character transition rate. We then fitted models in which only the speciation rate $(\lambda)$ varied between states, only the extinction rate $(\mu)$ varied, and finally, one in which neither $\lambda$ nor $\mu$ vary, but the transition rates differ between types of transitions. 
bioRxiv preprint doi: https://doi.org/10.1101/2020.12.17.422867; this version posted December 18, 2020. The copyright holder for this preprint (which was not certified by peer review) is the author/funder, who has granted bioRxiv a license to display the preprint in perpetuity. It is made available under aCC-BY 4.0 International license.

We then fitted a more complex model in which all rates of speciation and extinction depended on the character state for our multi-state character. To rank and choose among the different models with speciation and extinction rates, we used the Akaike information criterion (AIC). Using information theory and AIC, we computed the relative weight of evidence in favor of each of our different hypotheses using AIC weights and chose the best model [19]. With the best (selected) model, we run a Bayesian MCMC. We run our chain with 9,000 steps.

In addition, and to understand the evolution of habitat use among these gorgonians, we estimated habitat use values for ancestral nodes in the inferred phylogenetic tree. We modeled our characters using a discrete approach using a continuous-time Markov chain model commonly known as the Mk model. We then fitted a single-rate model and reconstructed ancestral states at internal nodes in the phylogeny. We used the function lik.anc to estimate the marginal ancestral states. As an alternative way to reconstruct states at ancestral nodes, we sampled character histories from their posterior probability distribution using an MCMC approach, known as the "stochastic character mapping" [20] with the make.simmap function in package "phytools" [21]. In this latter approach, we obtained a sample of histories for our discrete character's evolution on the phylogeny - rather than a probability distribution for the character at nodes. Since a single reconstruction is meaningless, we iterated the process 1,000 times and evaluated the distribution from these stochastic maps. To generate a summary of these maps, we estimated the number of changes of each type, the proportion of time spent in each state, and the posterior probabilities that each internal node is in each state, under our model.

\section{Results}

The obtained time-calibrated phylogeny showed high support values for all studied lineages at the genus level and major recognized clades (See supplementary Fig. 1). Overall, there were trends separating shallow, mesophotic, and deep gorgonian species but multiple shifts to different depth ranges occurred. Colonization of Caribbean MCEs happened even at the oldest octocoral lineages, i.e., stem age > 100 MYA, such as Trychogorgia lyra (Chrysogorgiidae) a species within the deep-sea clade of highly calcified octocorals (Calcaxonia) (Fig. 1, clade A). Despite gorgonian corals forming similar branching tree-like colonies and 
habitat-forming characteristics, they are a polyphyletic group including old deep-sea lineages lacking hard or proteinaceous skeletons, also known as scleraxonians (Fig. 1, clades B and C) closely related with soft corals, which include common Caribbean MCE members such as /ciligorgia and Diodogorgia [22,23]. Preceded by a clade of deep-sea stoloniferous octocorals, the true gorgonian corals (Fig. 1, clade D), i.e., with an axial proteinaceous skeleton, grouped in a large younger clade (<100 MYA stem age), contained modest phylogenetic resolution with several patterns that we describe below.

First, we find a clade including Acanthogorgiidae (Acanthogorgia spp.), Hypnogorgia and the family Keroeididae (Thelogorgia) (Fig. 1, clade E), along with two shallow-water groups, Muriceopsis and Pterogorgia, that are usually attracted to disparate clades in the octocoral phylogeny probably due to long branch attraction [22,24]. Second, part of the paraphyletic family Plexauridae in the clade known as 'Stenogorgiinae' [25] arises in the tree, most reaching mesophotic depths, but also found at depths below 200 m such as Lytreia, Muriceides, Heterogorgia (only shallow-water), Caliacis, Echinomuricea and Eunicella singularis (Fig. 1, clade F). Third, we notice Ellisellidae clade, a major component of the mesophotic gorgonian coral assemblage, attaining high densities in the upper MCE range $[1,12,26]$, and the only group where MCEs promoted its entire diversification (Figure 1, clade G). This group, extending also to deeper ecosystems, is the only one found in MCEs worldwide [27], and its simultaneous parallel evolution [28] suggests that MCEs could be an important factor in their diversification.

Last, we see the shallow-water gorgonian corals, including all zooxanthellate species from the Caribbean, and the azooxanthellate, including aposymbiotic Muricea [27], from the Tropical Eastern Pacific, appear in two clades that we can assign to the families Plexauridae (in part) and Gorgoniidae, major components of the shallow-water communities (Fig. 1, clades H and I). Plexauridae includes mesophotic-associated genera such as Scleracis, Swiftia (in part), and Thesea, some groups including shallow and mesophotic groups like Leptogorgia and Eugorgia [29], azooxanthellate shallow-water Pacifigorgia and Psammogorgia, the zooxanthellate Plexaurella, Gorgonia, Phyllogorgia and Antillogorgia, the latter includes some mesophotic gorgonian corals (Fig. 1, clade H). The Plexauridae clade has the Caribbean Swiftia exserta as sister clade, with species in both Caribbean and the Tropical Eastern Pacific, and diverse Caribbean zooxanthellate shallow-water groups, Pseudoplexaura, Plexaura, Muricea and Eunicea (Fig. 1, clade I), which includes mostly 
bioRxiv preprint doi: https://doi.org/10.1101/2020.12.17.422867; this version posted December 18, 2020. The copyright holder for this preprint (which was not certified by peer review) is the author/funder, who has granted bioRxiv a license to display the preprint in perpetuity. It is made available under aCC-BY 4.0 International license.

mesophotic species [1]. Some of these symbiotic mesophotic species (e.g., Muricea laxa and Antillogorgia

hystrix), are likely the product of shallow-deep ecological divergence, similar to the incipient cases of Eunicea flexuosa and Antillogorgia bipinnata [30,31], but today reaching depths below $40 \mathrm{~m}$. There were multiple unresolved relationships in the octocoral phylogeny observed recurrently, even with the largest amount of phylogenetic information [32], which together with the placement of Ellisellidae, are beyond the scope of this article and deserve further systematic revision [23].

Overall speciation was faster in mesophotic and shallow-water gorgonian clades. Yet, less extinction was detected in the deep-sea lineages. Remarkable, net diversification rates were faster in mesophotic lineages followed by shallow and deep clades (Fig. 2). In addition, mesophotic gorgonian corals had multiple deep-sea origins. Shallow-water gorgonian lineages, which are more abundant in the sampling and apparently more speciose, were restricted to less clades than mesophotic gorgonians, which revolutionize from several deepsea ancestors (Figs. 1-2).

\section{Discussion}

The little genetic divergence within species from shallow-water genera in the Caribbean and Tropical Eastern Pacific have been noted by several authors [24,25,33-37]. Apart from the families Plexauridae and Gorgoniidae, where ecological divergence is suspected as the gorgonian assemblage colonizes the upper MCEs (30-60 m), the relationship between shallow-mesophotic species was rarely observed in closely related species in most clades. This pattern is also found in reef fishes and scleractinian corals [38]. Although reefbuilding scleractinian corals can colonize deeper into MCEs $[10,39,40]$, the azooxathellate cup corals replaces the hermatypic coral assemblage [12] and belongs to very old (>77 MYA) Scleractinian lineages, dominating this environment and even deeper waters [41].

The families Plexauridae and Gorgoniidae showed replicated patterns of sister species segregated by shallow and mesophotic habitats consistent with recent research showing how depth plays a major role in the diversification of reef organisms $[31,42]$. The shallow-deep gradient creates an intermediate scenario between adaptive plasticity and local adaptation, which is common several Caribbean species [4,30]. Estimates of 
bioRxiv preprint doi: https://doi.org/10.1101/2020.12.17.422867; this version posted December 18, 2020. The copyright holder for this preprint (which was not certified by peer review) is the author/funder, who has granted bioRxiv a license to display the preprint in perpetuity. It is made available under aCC-BY 40 International license.

young diversification between pairs of habitat-segregated pairs of species is consistent with recent

demographic models inferred from genomic data [43]. Our phylogenetic reconstruction suggests that such a shallow-mesophotic diversification has occurred at least nine times in these two families, pointing out by the first time, to the major role and the macroevolutionary magnitude of depth/light promoting the formation of new species in the Caribbean. We suspect that ecological specialization mediated by immigrant inviability, as suggested previously [31], mediates the formation of these young pairs of segregated species in shallow and mesophotic habitats.

Mesophotic gorgonian corals in the Caribbean, also excluding Plexauridae and Gorgoniidae, have close memberships with deep-sea groups and can be located at the shallower records of those lineages [3,44]. Gorgonians living at mesophotic depths (45-182 m) exceed the geographical/latitudinal bounds of shallowwater species [45], which supports the idea of their independent evolutionary history. Two families, which most species distribute within the MCE range, Keroeididae, with all species of the genus Thelogorgia [46] and Ellisellidae, which suggest the MCE depth range and environment can be considered an important feature for octocoral diversification. Previous observations in the upper mesophotic zone (30-60m) from Caribbean reefs suggested that younger gorgonian species lineages are replaced by older lineages characterized by phylogenetically dispersed species, which have thinner branches and smaller polyps than shallow-water species [47]. Likewise, polyp density decreases with depth in gorgonian corals [48], which has been hypothesized as a response to an increasing microbial metabolism due low water-motion and anoxia with depth [1]. In general, mesophotic gorgonian corals in the Caribbean are not related to their shallow-water counterparts and consequently, mesophotic depths do not serve as a refuge for shallow gorgonians excluding Plexauridae and Gorgoniidae, where MCEs are being colonized back. Interestingly, mesophotic clades seem to have faster diversification rates than both shallow and deep-water gorgonians (Fig. 2).

\section{Acknowledgments}

The support from Bluelife dive shop (family Garcia) was fundamental to accomplish this study. The San Andres Hospital kindly supplied medical oxygen for CCR. We are very grateful with Gregg Stanton, Wakulla Dive Center, for continuing support and advise for deep diving. We are thankful with Nacor Bolaños, Julio Andrade, Fabian García, Santiago Herrera, 
bioRxiv preprint doi: https://doi.org/10.1101/2020.12.17.422867; this version posted December 18,2020 . The copyright holder for this preprint (which was not certified by peer review) is the author/funder, who has granted bioRxiv a license to display the preprint in perpetuity. It is made available under aCC-BY 4.0 International license.

Mariana Gnecco, Manu Forero, Deibis Seguro, Oscar Ruiz, Federico Botero and Camilo Martinez for fieldwork support.

We recognize the participation and support from local communities.

\section{Ethical Statement}

Our project grant (COLCIENCIAS No. 120465944147) was reviewed by Universidad de los Andes ethical committee and found it "low risk". All permits and collecting protocols met the Colombian laws.

\section{Funding Statement}

This research was partially funded by the agreement between Corporación para el Desarrollo Sostenible del Archipiélago De San Andrés, Providencia y Santa Catalina - Coralina and Universidad de los Andes-UniAndes (Agreements 13-14 and 21-15) and COLCIENCIAS (grant No. 120465944147), Colombia. Additional funding was possible thanks to Vicerrectoria de Investigaciones, Programas de Investigación-Especiación Ecológica (UniAndes).

\section{Data Accessibility}

DNA sequences: New sequences have GenBank Accession Numbers MN046013- MN046103.

Phylogenetic data, including alignments: TreeBASE accession number pending.

\section{Competing Interests}

We have no competing interests.'

\section{Authors' Contributions}

JAS, FLG-Z and LFD conceived the study. JAS, FLG-Z, CP and LFD ran the analyses. JAS wrote the manuscript with the help of FLG-Z, LFD and CP. All authors approved the final version of the article.

\section{References}

1. Sánchez JA et al. 2019 Gorgonian

Corals (39). In Loya et al. (eds) Mesophotic

Coral Ecosystems, pp. 727-745. Springer

Nature Switzerland AG.

2. Baker EK, Harris PT. 2016

Mesophotic Coral Ecosystems: A Lifeboat for Coral Reefs? United Nations Environment

Programme and GRID-Arendal.

3. Quattrini AM, Georgian SE, Byrnes

L, Stevens A, Falco R, Cordes EE. 2013 Niche

divergence by deep-sea octocorals in the genus

Callogorgia across the continental slope of the

Gulf of Mexico. Mol. Ecol. 22, 4123-4140.

(doi:10.1111/mec.12370)
4. Sánchez JA. 2017 Diversity and evolution of octocoral animal forests at both sides of tropical America. Mar. Anim. For. Ecol. Benthic Biodivers. Hotspots, 111-143.

5. Pérez $C D$, Neves $B$ de $M$, Cordeiro RT, Williams GC, Cairns SD. 2016 Diversity and Distribution of Octocorallia. In The Cnidaria,

Past, Present and Future, pp. 109-123. Springer, Cham. (doi:10.1007/978-3-31931305-4_8)

6. Grasshoff M. 1988 The genus Leptogorgia (Octocorallia: Gorgoniidae) in West Africa. Atlantide Rep. 14, 91-147.
7. Devictor ST, Morton SL. 2010 Identification guide to the shallow water (O$200 \mathrm{~m}$ ) octocorals of the South Atlantic Bight. Zootaxa 2599, 1-62.

8. Perez $C D$, Neves BM, Oliveira DH. 2011 New records of octocorals(Cnidaria: Anthozoa) from the Brazilian coast. Aquat. Biol. 13, 203-214.

9. Previati M, Scinto A, Cerrano C, Osinga R. 2010 Oxygen consumption in Mediter ranean octocorals under different temperatures. J. Exp. Mar. Biol. Ecol. 390, 3948. 
bioRxiv preprint doi: https://doi.org/10.1101/2020.12.17.422867; this version posted December 18, 2020. The copyright holder for this preprint (which was not certified by peer review) is the author/funder, who has granted bioRxiv a license to display the preprint in perpetuity. It is made available under acc.-BY 4.0 International license.

10. Gonzalez-Zapata FL, Bongaerts $\mathrm{P}$, Ramírez-Portilla C, Adu-Oppong B, Walljasper G, Reyes A, Sánchez J. A JA. 2018 Holobiont Diversity in a Reef-Building Coral over Its Entire Depth Range in the Mesophotic Zone. Front Mar. Sci. 5. (doi:10.3389/fmars.2018.00029)

11. Gonzalez-Zapata FL, Gómez-Osorio S, Sánchez JA. 2018 Conspicuous endolithic algal associations in a mesophotic reef-building coral. Coral Reefs 37, 705-709.

12. Sánchez JA, González-Zapata FL, Dueñas LF, Andrade J, Pico-Vargas AL, Vergara DC, Sarmiento A, Bolaños N. 2019 Corals in the Mesophotic Zone (40-115 m) at the Barrier Reef Complex From San Andrés Island (Southwestern Caribbean). Front. Mar. Sci. 6. (doi:10.3389/fmars. 2019.00536)

13. Coffroth MA, Lasker HR, Diamond ME, Bruenn JA, Bermingham E. 1992 DNA fingerprints of a gorgonian coral: A method for detecting clonal structure in a vegetative species. Mar. Biol. 114.

14. Ardila NE, Giribet $G$, Sánchez JA. 2012 A time-calibrated molecular phylogeny of the precious corals: reconciling discrepancies in the taxonomic classification and insights into their evolutionary history. BMC Evol. Biol. 12, 246

15. Thorne JL, Kishino H. 2002

Divergence time and evolutionary rate estimation with multilocus data. Syst. Biol. 51, 689-702.

16. Hayward BW. 1977 Lower Miocene corals from the Waitakere Ranges, North Auckland, New Zealand. J. R. Soc. N. Z. 7, 99111.

17. Kocurko MJ, Kocurko DJ. 1992 Fossil Octocorallia of the Red Bluff Formation, lower Oligocene, Mississippi. J. Paleontol. 66, 594-602.

18. Fitzlohn RG. 2012 Diversitree: comparative phylogenetic analyses of diversification in R. Methods Ecol. Evol. 3, 1084-1092.

(doi:https://doi.org/10.1111/j.2041-

210X.2012.00234.x)

19. Huelsenbeck JP, Nielsen R, Bollback JP. 2003 Stochastic Mapping of Morphological Characters. Syst. Biol. 52, 131-158. (doi:10.1080/10635150390192780) 20. Revell L. 2012 phytools: an R package for phylogenetic comparative biology (and other things). Methods Ecol. Evol. 3, 217223. (doi:10.1111/j.2041-210X.2011.00169.x) 21. McFadden C, France, Sánchez JA, Alderslade P. 2006 A molecular phylogenetic analysis of the Octocorallia (Cnidaria:

Anthozoa) based on mitochondrial proteincoding sequences. Mol. Phylogenet. Evol. 41, 513-527. (doi:10.1016/j.ympev.2006.06.010) 22. McFadden CS, Sánchez JA, France SC. 2010 Molecular Phylogenetic Insights into the Evolution of Octocorallia: A Review. Integr. Comp. Biol. 50, 389-410.

(doi:10.1093/icb/icq056)

23. Aguilar C, Sánchez JA. 2007

Phylogenetic hypotheses of gorgoniid octocorals according to ITS2 and their predicted RNA secondary structures. $\mathrm{Mol}$. Phylogenet. Evol. 43, 774-786.

24. Wirshing HH, Messing CG, Douady CJ, Reed. J, Stanhope MJ, Shivji MS. 2005 Molecular evidence for multiple lineages in the gorgonian family Plexauridae (Anthozoa: Octocorallia). Mar. Biol. 147, 497-508. (doi:10.1007/s00227-005-1592-y)

25. Sánchez JA. 1999 Black coraloctocoral distribution patterns in Imelda bank, a deep-water reef, Colombia, Caribbean sea. Bull. Mar. Sci. 65, 215-225.

26. Sánchez JA et al. 2018 Gorgonian corals. In Mesophotic coral ecosystems of the world (eds Y Loya, KA Puglise, T Bridge), pp. 133. New York: Springer International Publishing.

27. Bilewitch JP, Ekins M, Hooper J, Degnan SM. 2014 Molecular and morphological systematics of the Ellisellidae (Coelenterata: Octocorallia): Parallel evolution in a globally distributed family of octocorals. Mol. Phylogenet. Evol. 73, 106-118. (doi:10.1016/j.ympev.2014.01.023) 28. Breedy O, Guzman HM. 2013 A New Species of the Genus Eugorgia (Cnidaria: Octocorallia: Gorgoni idae) from Mesophotic Reefs in the Eastern Pacific. Bull. Mar. Sci. 89, 735-743. (doi:10.5343/bms.2013.1014)

29. Calixto-Botía I, Sánchez JA. 2017 A case of modular phenotypic plasticity in the depth gradient for the gorgonian coral Antillogorgia bipinnata (Cnidaria: Octocorallia) BMC Evol. Biol. 17. (doi:10.1186/s12862-0170900-8)

30. Prada C, Hell berg ME. 2013 Long prereproductive selection and divergence by depth in a Caribbean candelabrum coral. Proc. Natl. Acad. Sci. 110, 3961-3966. (doi:10.1073/pnas.1208931110) 31. Quattrini AM et al. 2018 Universal target-enrichment baits for anthozoan (Cnidaria) phylogenomics: New approaches to long-standing problems. Mol. Ecol. Resour. 18, 281-295. (doi:10.1111/1755-0998.12736)

32. Ament-Velásquez SL, Breedy O, Cortés J, Guzman HM, Wörheide G, Vargas S. 2016 Homoplasious colony morphology and mito-nuclear phylogenetic discordance among Eastern Pacific octocorals. Mol. Phylogenet. Evol. 98, 373-381.

33. Grajales A, Aguilar C, Sánchez JA 2007 Phylogenetic reconstruction using secondary structures of Internal Transcribed Spacer 2 (ITS2, rDNA): finding the molecular and morphological gap in Caribbean gorgonian corals. BMC Evol. Biol. 7.

34. Sánchez JA, MacFadden CS, France

SC, Lasker HR. 2003 Molecular phylogenetic

analyses of shallow-water Caribbean

octocorals. Mar. Biol. 142, 975-987.

(doi:10.1007/s00227-003-1018-7)

35. Vargas S, Guzman HM, Breedy O

Wörheide G. 2014 Molecular phylogeny and

DNA barcoding of tropical eastern Pacific

shallow-water gorgonian octocorals. Mar. Biol.

161, 1027-1038.

36. Wirshing HH, Baker AC. 2015

Molecular and Morphological Species

Boundaries in the Gorgonian Octocoral Genus

Pterogorgia (Octocorallia: Gorgoniidae). PLOS ONE 10, e0133517.

(doi:10.1371/journal.pone.0133517)

37. Rocha LA, Pinheiro HT, Shepherd B, Papastamatiou YP, Luiz OJ, Pyle RL, Bongaerts

P. 2018 Mesophotic coral ecosystems are threatened and ecologically distinct from shallow water reefs. Science 361, 281-284. (doi:10.1126/science.aaq1614)

38. Bongaerts $\mathrm{P}$, Frade PR, Hay KB Englebert N, Latijnhouwers KR, Bak RP, Vermeij MJ, Hoegh-Guldberg O. 2015 Deep down on a Caribbean reef: lower mesophotic depths harbor a specialized coral-endosymbiont community. Sci. Rep. 5

39. Kahng SE, Copus JM, Wagner D. 2014 Recent advances in the ecology of mesophotic coral ecosystems (MCEs). Curr. Opin. Environ. Sustain. 7, 72-81.

40. Stolarski J, Kitahara MV, Miller DJ,

Cairns SD, Mazur M, Meibom A. 2011 The ancient evolutionary origins of Scleractinia revealed by azooxanthellate corals. BMC Evol. Biol. 11, 316.

41. Quattrini AM, Baums IB, Shank TM Morrison $\mathrm{CL}$, Cordes EE. 2015 Testing the depth-differentiation hypothesis in a deepwater octocoral. Proc. R. Soc. B Biol. Sci. 282, 20150008-20150008.

(doi:10.1098/rspb.2015.0008)

42. Bayer FM. 1961 The shallow water Octocorallia of the West Indian region, Martinus Nijoff, The Hague.

43. Bayer FM. 1991 Thelogorgia, a new genus of gorgonacean octocorals, with descriptions of four new species from the western Atlantic. Bull. Mar. Sci. 49, 506-537. 44. Velásquez J, Sánchez JA. 2015 Octocoral Species Assembly and Coexistence in Caribbean Coral Reefs. PloS One 10, e0129609. 45. Quattrini AM, Gómez CE, Cordes EE. 2017 Environmental filtering and neutral processes shape octocoral community assembly in the deep sea. Oecologia 183, 221236.

\section{Figures}


bioRxiv preprint doi: https://doi.org/10.1101/2020.12.17.422867; this version posted December 18,2020 . The copyright holder for this preprint (which was not certified by peer review) is the author/funder, who has granted bioRxiv a license to display the preprint in perpetuity. It is made available under aCC-BY 4.0 International license.

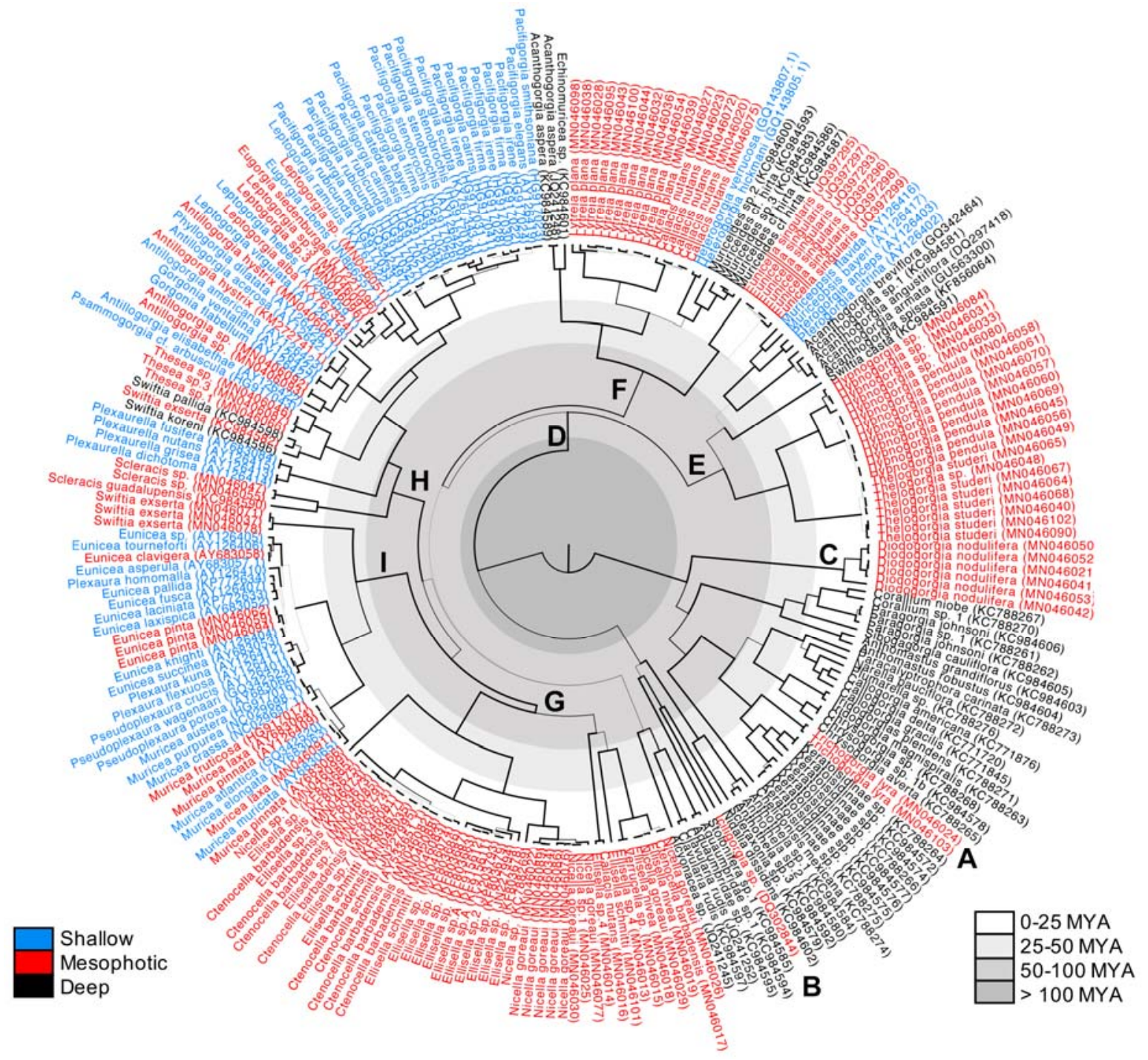

Figure 1. Time-calibrated phylogeny from 242 gorgonian coral species from shallow-, mesophotic-, and deepwater gorgonian corals from the Caribbean-Gulf of Mexico and the eastern tropical Pacific (mtMutS). Branch line width represents posterior probability support; thicker lines are supports $>0.9$. Important clades are labeled A-I correspond, which correspond to monophyletic lineages explained in the text. (See supplementary Figure 1 for the chronogram with error bars)
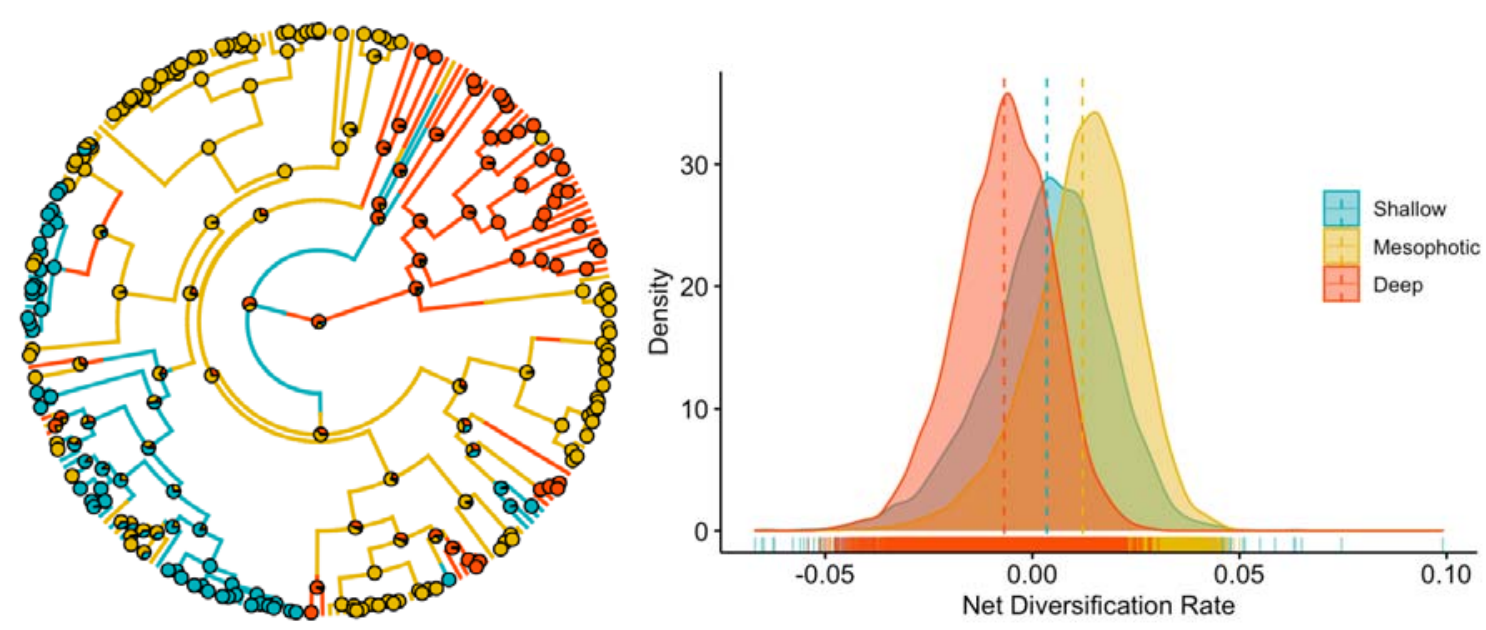
bioRxiv preprint doi: https://doi.org/10.1101/2020.12.17.422867; this version posted December 18,2020 . The copyright holder for this preprint (which was not certified by peer review) is the author/funder, who has granted bioRxiv a license to display the preprint in perpetuity. It is made available under aCC-BY 40 International license.

Figure 2. A. The phylogeny with a discreate character map based on a summary of 1,000 stochastic maps generated from modeling of the evolution of habitat use. Branches are colored depending on the habitat utilization by the different gorgonians. B. Rates of net diversification for shallow, mesophotic and deep-water gorgonians. Probability density plots are based on 9,000 MCMC samples of the full MuSSE model. 